\title{
手指，手関節の伸展障害に対する腱移行術の検討
}

\author{
鹿児島市立病院整形外科 \\ 牧信哉・谷口良康 \\ 濱 里 雄次郎・長 野 祐一 \\ 吉 野光・栫 博 則
}

\section{Follow-Up Study on Tendon Transfer for Extension Disturbance of Wrist, Thumb, and Finger}

by

Shinya Maki, Yoshiyasu Taniguchi, Yuujirou Hamasato, Yuuichi Nagano, Hikaru Yoshino and Hironori Kakoi

Department of Orthopaedic Surgery, Kagoshima City Hospital, Kagoshima, Japan

\begin{abstract}
In this report, we discuss nine patients with extension disturbance of the wrist, thumb, and fingers that were treated by the tendon transfer operation. There were five cases of brachial plexus injury and four cases of crush injury of the extensor tendons. The average age of the patients at operation was 23 years. The mean length of the postoperative follow-up was 4.1 years. The improvement of joint motion was acquired in $67 \%$ of the wrist cases, $86 \%$ of the thumb cases, and $75 \%$ of the finger cases. The results were poor in three cases, three in which two cases were brachial plexus injury and one was incomplete amputation of the wrist. The operation was unsuccessful due to evaluation failure of the mover in the two brachial plexus injury cases and adhesion of the transferred tendon in the incomplete amputation case.
\end{abstract}

Key words : tendon transfer (腱移行), brachial plexus injury（腕神経叢損傷）, extensor tendon (伸筋腱)

はじめに

今回, 我々は手指, 手関節の伸展障害に対し, 腱移 行術を行なった症例の術後の改善度を検討したので報 告したい.

\section{症例及び方法}

症例は平成 2 年 10 月より平成 8 年 5 月の間に，当 院にて手指, 手関節の伸展障害に対し, 腱移行術を行 なった 9 症例 9 手を対象とした。手術時年令は 15 歳 から 38 歳 (平均; 23 歳), 原因疾患は腕神経叢損傷; 5 症例（うち 1 例は分婏麻㽻）, 外傷による伸筋腱群
の挫滅； 4 症例であった。術後観察期間は 1 年 6 ケ月 から 8 年 10 ケ月（平均； 4 年 1 ケ月）であった。そ れらの症例に対し，1）移行腱の種類, 術前, 術後で の，2）手関節の伸展角度の改善度，3） II 〜 V手指 MP 関節，母指 IP 関節の伸展角度の改善度，4）握 力の改善，5）患者の意見，を調へ，成績不良例の原 因を検討した。

\section{結果}

1) 移行腱の種類 ; 手関節の伸展の再建は 9 例中 6 例で行ない，4 例では円回内筋（以下 PT 之略す）を, 2 例ではPT が力源として使えなかったため, 橈側手 


\begin{tabular}{|c|c|c|c|}
\hline 手関節の伸展 & & \multicolumn{2}{|l|}{$6 / 9$ 例 } \\
\hline $\mathrm{PT}$ & $\rightarrow$ & ECRL\&B & 4 例 \\
\hline FCR & $\rightarrow$ & & 2 \\
\hline II 〜 IV指の伸展 & \multicolumn{3}{|c|}{$8 / 9$ 例 } \\
\hline FCR & $\rightarrow$ & EDC & 5 例 \\
\hline FDSIV & $\rightarrow$ & & 3 \\
\hline 母指の伸展 & \multicolumn{3}{|c|}{$7 / 9$ 例 } \\
\hline $\mathrm{PT}$ & $\rightarrow$ & EPL & 7 例 \\
\hline
\end{tabular}

*4/7 で APL の腱固定

根屈筋（以下 FCR と略す）を，長，短橈側手根伸筋 （以下 ECRL \& B と略す）に繾合した. II 指〜IV指の 伸展の再建は， 9 例中 8 例で行ない, FCR を 5 例で, 環指の浅指屈筋 (以下 FDSIV と略す) を 3 例で使用 し，それを総指伸筋（以下 EDC と略す）に繾合した。 母指の伸展の再建は, 9 例中 7 例で行ない, 全例, 長 掌筋（以下 PL と略す）を長母指伸筋（以下 EPL と 略す）に縫合, 長母指外転筋腱（以下 APL と略す） の母指外転位での腱固定を 4 例で追加した（表 1 ）.

2 ) 手関節の伸展角度；6例中 4 例 (67\%) で改善 が得られた。改善例では, 術後 $50^{\circ} \sim 70^{\circ}$ (平均; $\left.57.5^{\circ}\right)$ 改善していた. 改善しない 2 例は, 両方とも 腕神経叢損傷 (うち 1 例は分婏麻疩) であった。

3）手指 MP 関節の伸展角度 ; 8 例中 6 例 (75\%) で改善が得られた. 改善例では, 術後, 各指で $30^{\circ}$ $70^{\circ}$ (平均; $50^{\circ}$ ) 改善していた。改善しない 2 例は, 分婏麻痖の症例之, 外傷による伸筋腱群の挫隇（不全 切断症例）であった，母指 IP 関節の伸展角度 ; 7 例 中6例 (86\%) で改善が得られた，改善例では， $30^{\circ} \sim$ $80^{\circ}$ (平均; $55^{\circ}$ ) 改善していた. 改善しない 1 例は, 分婏麻疸の症例であった。

4 ) 握力；9例中 7 例 (78\%) で改善が得られた。 改善例では, 術後 $5 \sim 17 \mathrm{~kg}$ (平均; $11 \mathrm{~kg}$ ) 改善して いた. 改善しない2 例は, 分婏麻疸の症例之, 外傷に よる伸筋腱群の挫隇（不全切断症例）であった.

5 ) 患肢の使用状况 ; 手術後の意見を聞いてみると, 腕神経叢損傷 5 例中 4 例で, 手術した手を補助手とし か使っていなかったが, 1 例では lateral cord のみ の損傷ということああって, 利き手として使用してい た. 外傷による伸筋腱群の挫堿例では, 全例利き手の 受傷ということもあって, 不全切断例を除く 4 例中 3
表 2 患肢の使用状況

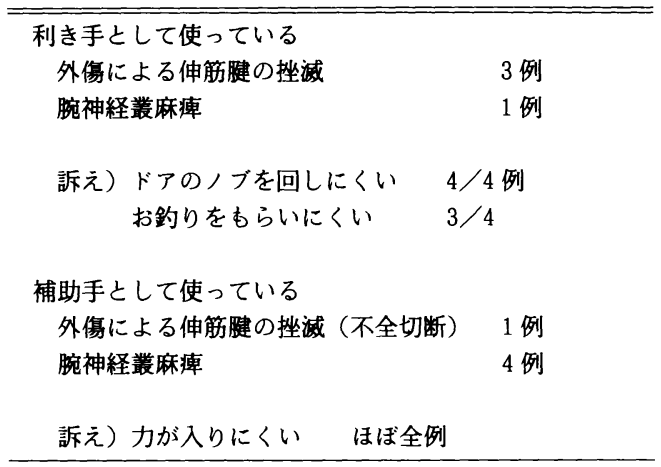

例で, 術後む利き手として使用していた，利き手とし て使っている 4 例で, 不満な点を聞いてみると，4例 全例で “ドアのノブが回しにくい”，3例で “おつり があらいにくい”と訴えていた. 補助手として使って いる 5 例では, 全例で “力がはいりにくい”之訴えて いた（表 2 ).

\section{考察}

今回の調查した症例のなかで，成績不良例をみてみ ると, 手関節の伸展再建では腕神経叢損傷と分婏麻疸 の各々 1 例, 母指を含む手指の伸展再建では, 分婏麻 瘦之不全切断の各々 1 例であり, この 2 例では握力む 改善していなかった．この原因を考えてみた場合，腕 神経叢損傷之分婏麻疸では, 周囲の軟部組織は問題な く, 術前の移行腱の筋力の評価が甘かったため, 移行 腱の筋力が得られなかった之考えている. 分婏麻疸を 含む腕神経叢損傷例では，力源となる腱が徒手筋力テ スト（以下 MMT と略す）で正常である " 5 "であ ることは少なく”，この 2 例の成績不良例では, 術 前 MMT “4” と判断したが，実際は “ 3 ” 以下で あったものと考えている. あう1例の成績不良例であ る外傷による伸筋腱群の挫隇（不全切断）例では, 移 行腱の周囲の組織の挫㙎が強く, いわゆる “Tissue Equilibrium" ${ }^{2}$ が十分でなく, 腱の滑走がうまくいか なかったためと考えている.

今回の症例のうち， 5 症例が分婏麻㾝を含む腕神経 叢損傷例で, 4 症例が外傷による伸筋腱群の挫隇であっ たが, 調查にて腕神経叢損傷例では術後も補助手とし 加っていないのに対し, 伸筋腱群の挫隇例では, 不 全切断の 1 例を除き, 残る 3 例は利き手の損傷であっ たが, 術後む利き手として使っていることがわかった. 
腕神経叢麻盘例で術後も補助手としか使っていない理 由は，1）手に知覚障害があること，2）移行腱の筋 力が MMT で " 4 " と弱く，そのため，握力も弱く なっていたためと考えている. 腕神経叢麻瘒例に腱移 行を行なう場合, やや緊張を強めに縫うことと, 手術 に過度の期待を持たせないようにすることが肝要であ ると考えている.

利き手として, 手をつかっている 3 例で, 日常生活 での不自由をきいてみると, 全員訴えていたのは, "ドアのノブをまわしにくい"ことであった，私達は 津下法(4)に準じて行なってきたが，ドアのノブをまわ すためには, 手関節と手指 MP 関節の伸展が同時に 行なわれねばならず, それができるには, EDC に移 行すべき力源として FCR でなく, Boyes 法 ${ }^{1)} に$ 準じ て，FDSを使うべきだったのかもしれない．今回 3 例でFDS IV を使用したが, 全例腕神経叢損傷例で 移行腱の筋力が MMT “4” のためか, そこまでの十 分な手指 MP 関節の伸展は得られなかった.

$$
\text { ま と め }
$$

1) 手指, 手関節の伸展障害に対しする腱移行術は
有用な手術と考えるが, 成績不良例の原因は, 移行腱 の䈘力の評価の誤り及び痹着によると考えられた.

2 ）外傷による伸筋腱群の挫隇症例では, 不全切断 の 1 例を除き, 日常生活であ有用な手として使用して いたが，腕神経叢損傷（分婏麻痺を含む）症例では, 腱移行を行ない可動域が改善しても補助手としかなっ ていなかった.

\section{考文 献}

1) Chuinard, R. G. et al. : Tendon transfers for radial nerve plasy. : Use of superficialis tendon for digital extension. J. Hand Sury., 3 : 560-570, 1978.

2) Green D. P. : Radial nerve palsy. In Operative Hand Surgery (third edition), pp. $1401-1417$. Edited by David P. Green, New York, Churchill Livingstone, 1993.

3）武田滝彦ら：前腕伸筋群麻㾴に対する Riordan 腱移行 術の経験 整形外科, $20: 1513-1514,1969$.

4) 津下健哉 : 高位橈骨神経麻疸に対する腱移行術 私の 手の外科（手術アトラス, 第 3 版）: 483-488, 東京, 南 江堂, 1995. 